\author{
PAWEL CZAPLIŃSKI \\ Wyższa Szkoła Pedagogiczna, Słupsk
}

\title{
Przemysł drzewny na Pomorzu Środkowym w procesie przeobrażeń gospodarczych
}

Przemysł drzewny odgrywa ważną rolę w strukturze gospodarczej Pomorza Środkowego, gdyż obok przemysłu spożywczego i skórzanego jest on najlepiej rozwinięty i najszerzej reprezentowany. Obejmuje produkcję płyt i sklejek, opakowań drewnianych i elementów stolarki budowlanej, ale przede wszystkim produkcję tarcicy i mebli.

Wprowadzenie na przełomie lat osiemdziesiątych i dziewięćdziesiątych systemu gospodarki rynkowej spowodowało istotne zmiany w dotychczasowym funkcjonowaniu, kierunkach rozwoju i przestrzennym rozmieszczeniu zakładów drzewnych. W latach 1990 1991 szeroki dostęp do surowca pozwalał na utrzymanie, a nawet wzrost produkcji, jednak przestarzałe technologie, a zwłaszcza niedostatek kapitału, spowodowały spadek produkcji oraz powolny, ale stały spadek zatrudnienia. Podkreślić należy, że w tym dziale wytwórczości szybko podjęto działania restrukturyzacyjne, które w 1994 r. w dość znacznym stopniu poprawiły sytuację finansową zakładów.

W prezentowanym artykule podjęto próbę analizy wielopłaszczyznowych zmian strukturalnych jakie zaszły po 1989 r. w przemyśle drzewnym Pomorza Środkowego. Dość dużo miejsca poświęcono także na podkreślenie historycznych uwarunkowań rozwoju, jako podstawy do wnioskowania o kształcie struktury i drogi specjalizacji w przyszłości.

Problematyka przemian struktur przestrzenno-gałęziowych przemysłu Pomorza Środkowego znalazła już swoje odzwierciedlenie w pracach m.in. E. Rydza, E. Rydza i I. Jażewicz (1994), A. Suszyńskiego, B. Zdrojewskiej. Jednak ze względu na brak opracowań dotyczących wyłącznie przemysłu drzewnego, posłużono się materiałami pierwotnymi, które uzyskano w urzędach statystycznych w Słupsku i Koszalinie. Wykorzystano także adresy zakładów funkcjonujących w systemie Regon na dzień 30.06.1997 r. w klasach $20.10-20.40$ oraz w grupie 36.1 . 
ZARYS ROZWOJU PRZEMYSŁU DRZEWNEGO NA POMORZU ŚRODKOWYM

Bogate tradycje przerobu drewna na Pomorzu Środkowym sięgają końca XVIII w., kiedy to powstały pierwsze warsztaty rzemieślnicze i manufaktury. Za najstarsze uważa się założoną w 1764 r. papiernię w miejscowości Kłos pod Koszalinem (Gasztold i in. 1974) oraz tartaki w rejonie Słupska, Bytowa, Szczecinka, Człuchowa i Sławna.

Zasadnicze przeobrażenia strukturalno-produkcyjne branży drzewnej zaznaczyły się dopiero po $1850 \mathrm{r}$. Wówczas to $\mathrm{w}$ wielu zakładach proces produkcji rękodzielniczej zastąpiono zmechanizowaną produkcją fabryczną. W 1834 r. oddano do użytku fabrykę papieru w Koszalinie, a w latach 1840-1845 dwie fabryki rodziny Beckerów w Shupsku. W tym też okresie zaczęła funkcjonować fabryka zapałek w Sianowie ${ }^{*}$. Wymienione zakłady wyznaczyły kierunki rozwoju oraz profil produkcji przemysłu drzewnego w rejonie Słupska aż do II wojny światowej.

Mimo że peryferyjne położenie rejencji koszalińskiej a także partykularne interesy junkierstwa nie dawały zbyt wielkich szans na uprzemysłowienie tego regionu, protekcyjna polityka władz w Berlinie zadecydowała o powstaniu w II połowie XIX w. kilku nowych zakładów. W Koszalinie obok fabryki papieru wybudowano w 1871 r. fabrykę celulozy, natomiast Słupsk rozwijał się jako duży ośrodek meblarstwa. W 1893 r. na terenie miasta zlokalizowanych było 6 fabryk mebli i 5 ściśle z nimi współpracujących tartaków. Zatrudniały one w tym czasie ogółem około 1000 osób. Klasyfikowało to branżę drzewną na pierwszym miejscu w pozarolniczej strukturze produkcji miasta (Lindmajer i in. 1986). Niestety, negatywnym zjawiskiem przy decyzjach lokalizacji inwestycji okazała się nadmierna koncentracja kapitału w Słupsku i Koszalinie. W konsekwencji przemysł drzewny poza tymi ośrodkami ograniczał się do pojedynczych małych zakładów. Należały do nich: fabryki mebli w Świdwinie, Sławnie i Bytowie, fabryki zapałek w Lęborku i Sianowie ${ }^{* *}$, zakłady przetwórstwa drzewnego w Lęborku, Szczecinku i Sławnie oraz papiernie w Dębnicy Kaszubskiej i Kępicach.

Działania wojenne 1914-1918 nie wpłynęły bezpośrednio na funkcjonowanie całej branży. Jednak postanowienia traktatu wersalskiego (m.in. zerwanie więzów gospodarczych z ziemiami, które po wojnie weszły w skład państwa polskiego) spowodowały pewien regres. Wiele zakładów jako nierentowne zamknięto, inne w wyniku trudności ze zbytem ograniczyły produkcję. Nadal jednak znaczne powierzchnie leśne pozwalały na funkcjonowanie tartaków w rejonie Słupska, Świdwina, Bytowa, Sławna, Lęborka i Szczecinka. Również fabryki mebli w Słupsku, Białogardzie, Koszalinie, Sławnie i Bytowie do końca lat dwudziestych prowadziły działalność produkcyjną. W Słupsku mieściły się największe na omawianym terenie zakłady meblarskie, zatrudniające wraz z zakładami rzemieślniczymi ponad 2000 osób (Machura 1974). Jakość produkowanych mebli, głównie zestawów sypialnych, w fabrykach Beckera, Krugera i Nitschkego znana była na terenie całych Niemiec.

\footnotetext{
* Zakład uruchomiony w 1845 r. początkowo jako manufaktura.

** W Sianowie u schyłku XIX w. wybudowano drugą fabrykę zapałek.
} 
W latach trzydziestych obecnego stulecia w wyniku ogólnoświatowego kryzysu gospodarczego nastąpiło załamanie produkcji. Gwałtownie zwiększyło się bezrobocie. Zatrudnienie w przemyśle drzewnym zmniejszyło się o $25 \%$. W mniejszych ośrodkach, np. w Bytowie, fala zwolnień objęła $90 \%$ ogółu pracujących, zaś w Lęborku 100\%. Krytyczny okazał się rok 1933, kiedy to liczba bezrobotnych w rejencji koszalińskiej osiagnnęła poziom 19,5 tys.

Lata II wojny światowej przyniosły duże straty substancji majątkowej. Największe poniósł przemysł drzewny w powiatach: słupskim, białogardzkim i łobeskim, gdzie zniszczenia sięgały niekiedy $90 \%$. Najmniejsze straty (ok. 60\%) odnotowano w powiatach: szczecineckim, koszalińskim i bytowskim. Dotkliwie ucierpiały zwłaszcza papiernie w Koszalinie, Dębnicy Kaszubskiej i Kępicach. Wysoki 96\% poziom dewastacji tych obiektów zadecydował o ich całkowitej likwidacji. Tym samym branża papiernicza o 180-letniej tradycji na Pomorzu Środkowym przestała całkowicie istnieć*

Etap odbudowy zniszczeń wojennych trwał do końca 1949 r., ponieważ nakłady inwestycyjne oraz nieudolna polityka kredytowa uniemożliwiły wcześniejsze zagospodarowanie części zakładów, zwłaszcza tartaków. Stosunkowo dobra sytuacja towarzyszyła przejmowaniu

i uruchamianiu fabryk mebli i zakładów przetwórstwa drzewnego. Jako pierwsze oddano do użytku obiekty w Słupsku, Koszalinie i Świdwinie, a w latach 1946-1949 kolejne w Białogardzie, Łobzie, Złocieńcu, Bytowie, Słupsku i Drawsku Pomorskim (Machura 1974).

Drugi etap procesu odbudowy i rozwoju przemysłu drzewnego przypadł na lata 1950 1955. Cechowała go rozbudowa i modernizacja istniejących już obiektów oraz istotne zmiany organizacyjne. W $1950 \mathrm{r}$. powstały okręgowe przedsiębiorstwa przemysłu drzewnego z siedzibami w Słupsku i Szczecinku, skupiające 30 tartaków z nowo powstałego województwa koszalińskiego. Dość prężnie rozwijało się meblarstwo, zwłaszcza w Słupsku.

W ostatnim roku planu 6-letniego pracujący w przemyśle drzewnym stanowili 26,7\% ogółu pracujących w województwie. Stał się on więc drugim po przemyśle spożywczym źródłem utrzymania ludności pozarolniczej.

Po 1955 r. nastąił kolejny etap budowy nowoczesnego przemysłu, który miał na celu rozwiązanie narastających potrzeb gospodarki regionu, m.in. rozwój budownictwa i mieszkalnictwa. Stąd pod koniec lat pięćdziesiątych rozpoczęto zupełnie nowe inwestycje. W Szczecinku podjęto decyzję o budowie zakładu produkcji płyt wiórowych, a w Koszalinie fabryki płyt paździeżowych. Stworzono tym samym zupełnie nową dziedzinę przemysłu drzewnego na Pomorzu Środkowym. Rozruch technologiczny wymienionych zakładów nastapił na początku lat sześćdziesiątych, podobnie jak i nowych tartaków w Kołaczu i Bytowie. Wiele obiektów w tym okresie przeszło gruntowne modernizacje. Należały do nich m.in.: fabryka zapałek w Sianowie, zakłady stolarskie ${ }^{* *}$ w Człuchowie, Białogardzie i Bytowie. W 1960 r. nastapiła ważna zmiana organizacyjna, decydująca o dalszym rozwoju meblarstwa w regionie. Utworzony został Słupski Ośrodek Meblowy, który jako pierwszy

\footnotetext{
* W okresie powojennym odbudowano zakład produkcji tektury w Tarnówce (obecnie w granicach woj. pilskiego).

** Zakłady stolarskie zostały przekształcone w fabryki mebli.
} 
w skali kraju podjął produkcję opierającą się na ścisłej kooperacji i specjalizacji (Gierszewski 1981). W skład SOM weszły Słupskie Fabryki Mebli, jako przedsiębiorstwo wiodące, oraz Słupskie Zakłady Przemysłu Terenowego i Spółdzielnia Pracy „Dąb Pomorski” ze Słupska. Z czasem przystapiły do niego zakłady meblarskie z Koszalina, Bytowa i Darłowa. Zatrudnienie ośrodka szybko wzrastało, osiagając w 1975 roku 2,5 tys. osób.

Dalszy rozwój, zwłaszcza nowoczesnych gałęzi przemysłu drzewnego, dokonał się w latach siedemdziesiątych. W 1972 r. uruchomiono Fabrykę Płyt Pilśniowych i Wiórowych w Karlinie, a w 1976 r. jeden z największych i jak na owe czasy najnowocześniejszych w kraju zakładów przetwórstwa drzewnego „Sławodrzew” w Sławnie.

Niemały wpływ na funkcjonowanie wszystkich jednostek miała reforma administracyjna z 1975 r. Doszło wtedy do podziału zakładów skupionych w jednym okręgowym przedsiębiorstwie z siedzibą w Szczecinku. Część z nich została przejęta przez Słupskie Przedsiębiorstwo Przemysłu Drzewnego, do którego włączono również zakłady z byłego powiatu lęborskiego. Natomiast pozostałe zakłady weszły w skład Koszalińskiego Przedsiębiorstwa Przemysłu Drzewnego.

W okresie od 1976 r. do 1989 r. nie nastąpiła już zmiana struktury organizacyjnej. Nie odnotowano również żadnych nowych inwestycji (w sektorze państwowym), a jedynie modernizacje pojedynczych obiektów. Mimo to dynamika produkcji sprzedanej całej branży drzewnej w obu województwach kształtowała się w granicach $105-110 \%$ w stosunku do roku poprzedniego. Natomiast odwrotnie proporcjonalnie do produkcji kształtowało się zatrudnienie, które w 1989 r. wynosiło zaledwie 65\% stanu z 1975 r. Rok 1989 r. przyniósł kryzys w gospodarce narodowej, tym samym funkcjonowanie przemysłu drzewnego na dotychczasowych zasadach stało się niemożliwe.

\section{WARUNKI LOKALIZACJI}

Przyjmując podział czynników lokalizacji przemysłu za B. Kortusem (1986) i L. Pakułą, którzy wyróżniają czynniki przyrodnicze, ekonomiczno-techniczne i społeczno-polityczne, należy podkreślić, że struktura przestrzenna przemysłu drzewnego na Pomorzu Srodkowym, jest wypadkową przynajmniej kilku czynników działających równolegle i pod-legających czasowym zmianom.

Spośród czynników lokalizacyjnych znacząca rolę odgrywa czynnik surowcowy, który jest bazą i granicą możliwości rozwoju. W słupskim i koszalińskim obszary leśne zajmują odpowiednio 41,8\% i 37,2\% powierzchni województw, co oznacza powszechność występowania surowca, a tym samym łatwość pozyskania i transportu drewna. Przyczynia się także do swobody lokalizacji - zwłaszcza małych zakładów rozrastającego się sektora prywatnego. Zjawisko to powoduje znaczne rozproszenie produkcji (poza meblarstwem), a ponadto wpływa istotnie na rozdrobnienie rynku zbytu.

Równie ważnym czynnikiem wydaje się być siła robocza, przy czym należy rozróżnić dwa aspekty tego zagadnienia: siła robocza rozumiana jako liczba rąk do pracy oraz jako 
konkretny jej rodzaj i jakość. Z racji braku na Pomorzu Środkowym dużych ośrodków przemysłowych oraz zmian w rolnictwie uspołecznionym przemysł drzewny pełni funkcje aktywizacji regionów gospodarczo zaniedbanych (do których zaliczono m.in. gminy leżące w południowej czesści regionu, takie jak: Lipnica, Koczała, Przechlewo, Konarzyny, Wierzchowo, Czaplinek i Silnowo), gdyż przy małych wymaganiach dotyczących kwalifikacji pracowników - zwłaszcza w tartacznictwie - istnieje duże zapotrzebowanie ilościowe.

Według E. Małuszyńskiej (1996) za najważniejsze czynniki lokalizacji przemysłu na poziomie regionalnym uznano: dostęp do rynku, jakość dróg i usług kolejowych, pomoc finansową i siłę roboczą - jej cenę. Odnosząc je do przemysłu drzewnego w badanym regionie można sformułować następujące wnioski:

- na skutek wysokiego poziomu bezrobocia istnieje duża konkurencyjność na rynku lokalnym, czego objawem jest tania siła robocza, tak istotna przy wysokoim stopniu pracochłonności;

- niskie koszty pracy, dzierżawy lub kupna ziemi, a także niskie w porównaniu z innymi gałęziami zainwestowanie techniczne umożliwia uruchomienie produkcji bez znaczącej pomocy finansowej państwa. Przykładem może być produkcja palet w wielu zakładach w rejonie Miastka i Drawska Pomorskiego;

- sieć linii kolejowych przebiegających przez duże obszary leśne, a jednocześnie łączacych wielkie ośrodki miejskie (potencjalne rynki zbytu, np. Gdańsk, Szczecin) określa sprzyjająca dostępność przestrzenną. Dlatego też zarówno już istniejące, jak i nowe ośrodki produkcji (np. w Kobylnicy, Łebieńcu, Grzmiącej i in.) posiadają kolejowe połączenia transportowe uzupełniane przez transport drogowy. Wyjątkiem jest produkcja palet, gdyż ich wywóz do Niemiec i Holandii odbywa się wyłącznie transportem samochodowym.

\section{STRUKTURA WIELKOŚCIOWA I WŁASNOŚCIOWA}

W połowie 1997 r. funkcjonowały na Pomorzu Środkowym 1452 podmioty gospodarcze zaliczane do przemysłu drzewnego. Zdecydowana większość z nich (87\%) to jednostki małe, w których liczba pracujących nie przekracza 6 osób. Natomiast duże zakłady (powyżej 500 pracujących) stanowią zaledwie $0,3 \%$ ogółu (tab.1).

Tabela 1. Podmioty gospodarcze działające w systemie Regon zaliczone do przemysłu drzewnego w woj. słupskim i koszalińskim (VI 1997 r.)

\begin{tabular}{|l|c|c|c|c|c|c|}
\hline \multirow{2}{*}{$\begin{array}{c}\text { LICZBA } \\
\text { PRACUJAC_CYCH }\end{array}$} & \multicolumn{3}{|c|}{ PODMIOTY GOSPODARCZE } & \multicolumn{2}{c|}{ RAZEM } \\
\cline { 2 - 6 } & $\begin{array}{c}\text { WOJ. } \\
\text { KOSZALIŃSKIE }\end{array}$ & \multicolumn{2}{c|}{$\begin{array}{c}\text { WOJ. } \\
\text { SŁUPSKIE }\end{array}$} & \multicolumn{2}{c|}{} \\
\cline { 2 - 7 } & LICZBA & $\%$ & LICZBA & $\%$ & LICZBA & $\%$ \\
\hline $1-6$ & 557 & 86,0 & 706 & 87,7 & 1263 & 87,0 \\
\hline $7-100$ & $80^{\mathrm{A}}$ & 12,4 & 90 & 11,2 & 170 & 11,7 \\
\hline $101-500$ & $8^{\mathrm{A}}$ & 1,3 & 8 & 1,0 & 16 & 10,0 \\
\hline POW. 500 & 2 & 0,3 & 1 & 0,1 & 3 & 0,3 \\
\hline OGÓŁEM & 647 & 100,0 & 805 & 100,0 & 1452 & 100,0 \\
\hline
\end{tabular}


Uwaga: A - dane szacunkowe

Źródło: Opracowanie własne na podstawie danych z urzędów statystycznych w Słupsku i Koszalinie

Do największych zakładów pod względem zatrudnienia należą: Słupskie Fabryki Mebli sp. z o.o. z siedzibą w Słupsku i Koszalińskie Przedsiębiorstwo Przemysłu Drzewnego S.A. z siedzibą w Szczecinku. W obu wymienionych zakładach zatrudnienie kształtuje się na poziomie 960 osób.

Spośród 189 firm o zatrudnieniu powyżej 6 osób zaledwie 3 reprezentują sektor w pełni publiczny. Pozostałe - o różnych formach własności - należą do sektora prywatnego (tab. 2).

Tabela 2. Struktura własnościowa zakładów przemysłu drzewnego Pomorza Środkowego (VI 1997 r.)

\begin{tabular}{|l|c|c|c|}
\hline \multicolumn{1}{|c|}{ Forma własności } & woj. słupskie & woj. koszalińskie & Razem \\
\hline spółka cywilna & - & 3 & 3 \\
\hline $\begin{array}{l}\text { spółka z ograniczoną } \\
\text { odpowiedzialnością }\end{array}$ & 32 & 32 & 64 \\
\hline spółka cywilna & 15 & 14 & 29 \\
\hline $\begin{array}{l}\text { osoby fizyczne prowadzące } \\
\text { działalność gospodarczą }\end{array}$ & 36 & 54 & 90 \\
\hline przedsiębiorstwa państwowe & 2 & 1 & 3 \\
\hline OGÓŁEM & 85 & 104 & 189 \\
\hline
\end{tabular}

Źródło: Opracowanie własne na podstawie danych z urzędów statystycznych w Słupsku i Koszalinie

Najliczniejszą grupę reprezentuje własność osób prywatnych (około 50\%), jednak są to zazwyczaj niewielkie zakłady o znaczeniu regionalnym, rzadziej krajowym. Pozostałe przedsiębiorstwa posiadają status spółki, z których najwięcej, bo $35 \%$, to spółki z ograniczoną odpowiedzialnością. Tę formę własności posiadają największe zakłady w woj. słupskim, m.in. Słupskie Fabryki Mebli w Słupsku, Flair Poland w Kobylnicy, Poltarex w Lęborku. Natomiast w woj. koszalińskim duże zakłady mają charakter spółek akcyjnych. Należą do nich Koszalińskie Przedsiębiorstwo Przemysłu Drzewnego z siedzibą w Szczecinku i Alpex-Karlino w Karlinie.

Rozpatrując strukturę własnościową należy również podkreślić duży udział kapitału obcego niemieckiego. Zjawisko to dotyczy wszystkich badanych branż. Dwa największe zakłady meblarskie, tj. SFM w Słupsku i Flair Poland w Kobylnicy, należą do Schieder Mobel Holding z Niemiec, który na terenie całej Polski skupia 20 zakładów tej branży. Spośród innych dużych zakładów na uwagę zasługuje zakład stolarki budowlanej „Seeger Dach" w Łebieńcu koło Łeby należący do kapitału niemieckiego a także fabryka płyt w Szczecinku należąca do koncernu Kronospan z Austrii. Większość inwestorów zagranicznych lokuje swój kapitał w mniejszych, a czasem w bardzo małych firmach, np. firma niemiecka SLG Industrie und Handel GmbH w Kawczu lub szwedzki Westwood AB w Drzonowie. W każdej z tych firm liczba pracujących nie przekracza 100 osób. Duża stopa bezrobocia w regionie, a tym samym tania siła robocza a nawet ulgi inwestycyjne, wobec ogromnych kosztów kapitałowych oraz nakładów na wdrażanie nowych technologii 
nie są wystarczającym argumentem (zapewniającym szybki zysk) dla inwestorów zagranicznych. Dlatego też część nawet dużych zakładów, jak np. Alpex-Karlino, posiada mieszany kapitał zagraniczny.

Według danych, które uzyskano bezpośrednio w zakładach zatrudniających powyżej 5 osób, 31 z nich wykazało udział kapitału zagranicznego, głównie niemieckiego, a w dalszej kolejności szwedzkiego i duńskiego. Podkreślić należy jednak, że nie jest to pełna liczba, gdyż wiele firm nie udzieliło informacji na ten temat.

\section{STRUKTURA PRZESTRZENNA}

Przeprowadzona analiza wskazuje, że najbardziej charakterystycznym typem zakładów przemysłu drzewnego na Pomorzu Środkowym są tartaki (ryc. 1). Z ogólnej liczby 54 to zakłady, w których pracuje ponad 5 osób. Większość z nich (30) zlokalizowana jest w woj. słupskim. Do największych zalicza się zakład „Sławodrzew” w Sławnie (ok. 320 pracujących) oraz w Bielsku Pomorskim (ok. 130 pracujących). Natomiast w woj. koszalińskim największe tartaki zlokalizowane są w Świerszczynie, Wierzchowie i Kołaczu. Zatrudniają one od 110 do 120 osób każdy.

Ważnymi elementami struktury są $\mathrm{w}$ większości nowo powstałe zakłady produkujące opakowania drewniane, głównie palety. Ich produkcja koncentruje się w rejonie Miastka i Bytowa (łącznie 14 zakładów) oraz w rejonie Drawska Pomorskiego (9 zakładów).

$\mathrm{W}$ produkcji mebli nie odnotowano $\mathrm{w}$ omawianym okresie znaczących przesunięć przestrzennych. Nadal na czołowym miejscu są Słupsk i Koszalin, znacznie dystansując pozostałe ośrodki, wśród których na uwagę zasługują dwa nowo powstałe zakłady w Grzmiącej i Kobylnicy. Również w produkcji płyt i sklejek nie nastąpiły istotne zmiany. Produkcja nadal koncentruje się w dwóch ośrodkach, tzn. w Karlinie i Szczecinku.

Największym przeobrażeniom podlega produkcja stolarki budowlanej. W latach 1992-1995 powstało około 30 małych i średnich zakładów w największych miastach Pomorza Środkowego, tj. w Słupsku, Koszalinie, Kołobrzegu i Lęborku.

Rozpatrując strukture przestrzenną przemysłu drzewnego w regionie należy stwierdzić, że wyraźna koncentracja zakładów widoczna jest w pasie od Drawska Pomorskiego i Świdwina do Bytowa i Człuchowa oraz wyspowo w rejonie Słupska, Koszalina i Lęborka. Pozostałe obszary, cechujące się słabą dostępnością komunikacyjną i peryferyjnym położeniem, nie posiadają już tak wielu zakładów. 
PRODUKCJA W LATACH 1990-1995

Istotnym czynnikiem, w sposób adekwatny określającym kondycję badanej dziedziny wytwórczości jest wielkość produkcji sprzedanej. Zjawisko to przedstawiono w ujęciu dynamicznym za pomocą indeksu prostego o podstawie zmiennej (ryc. 2). 
Ryc. 1. Struktura przestrzenna przemysłu drzewnego na Pomorzu Środkowym. Stan na 30.06.1997 r.

Ryc. 2. Dynamika produkcji sprzedanej tarcicy i mebli na Pomorzu Środkowym

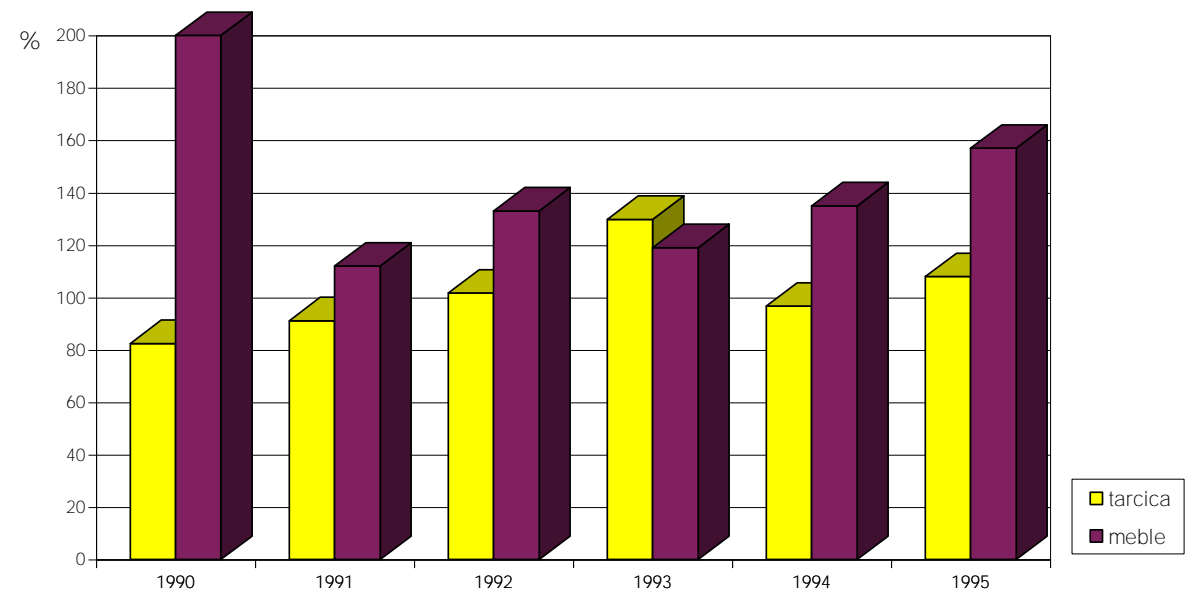

Ryc.2 Dynamika produkcji sprzedanej tarcicy i mebli na Pomorzu Środkowym

Jak wynika z prezentowanych danych regularny wzrost produkcji sprzedanej tarcicy notowany do 1993 r. uległ w kolejnych latach wyraźnemu zahamowaniu. Głównymi przyczynami tego zjawiska były duże wahania podaży drewna i stały wzrost jego ceny. Monopolistyczna pozycja Lasów Państwowych jako dostawcy surowca w latach 1993-1995 zaowocowała wzrostem cen o 220\%. Duży wpływ na szybki wzrost cen, zwłaszcza w 1993 roku, miało także wprowadzenie podatku VAT na tarcicę i jednocześnie wyłączenie z VAT surowca drzewnego, co postawiło w niekorzystnej sytuacji duże firmy przetwórstwa drzewnego, a drobnym wytwórcom, nie będącym płatnikami VAT, pozwoliło na oferowanie wyższych cen.

W 1994 r. mimo bardzo dobrej koniunktury w eksporcie, szczególnie na rynku niemieckim, odnotowano wyraźny spadek sprzedaży, co było efektem wcześniejszej polityki, tzn. sztucznie tworzonego deficytu podaży. Tak zwane „etaty cięć rębnych” wprowadzone przez Lasy Państwowe spowodowały spadek rentowności dużych zakładów przetwórstwa drzewnego. Jednym z nich jest „Sławodrzew” w Sławnie, który otrzymuje zbyt małe limity przetarcia drewna, by być rentownym. Jego rentowność od 1993 r. do końca 1995 r. spadła do $1 \%$. 
Od połowy 1995 roku zaobserwowano stabilizację cen drewna, na co wpływ miało zwolnienie z podatku VAT, a przede wszystkim malejąca opłacalność eksportu. Spowodowało to wzrost produkcji sprzedanej tarcicy w regionie, głównie za sprawą dwóch największych przedsiębiorstw, tj. Poltarex z Lęborka i KPPD ze Szczecinka. Ich wyniki finansowe

a zwłaszcza rentowność ${ }^{*}$ - odpowiednio 7,9\% i 4,6\%, lokowała obie firmy w ścisłej czołówce krajowej. Tak dobra kondycja ekonomiczna była wynikiem z jednej strony ograniczania taniego eksportu, a z drugiej rozszerzania oferty na rynku krajowym i wykorzystywania nowych kanałów dystrybucji.

Nieco inaczej w badanym okresie kształtowała się dynamika produkcji sprzedanej mebli. Gwałtowny spadek produkcji w latach 1990-1991 uwarunkowany załamaniem się rynku wschodniego, poważnymi kłopotami surowcowymi, upadkiem budownictwa mieszkaniowego, a przede wszystkim brakiem możliwości kredytowych związanych z modernizacją zakładów przyspieszył proces prywatyzacji. W 1992 r. udało się zahamować spadek produkcji a nawet osiagnięto wzrost w stosunku do roku poprzedniego o 15 punktów.

Lata 1994-1995 zaznaczyły się wzrostem produkcji sprzedanej mebli, co należy łączyć z orientacją eksportową sprywatyzowanych zakładów. Największy zakład regionu, SFM

w Słupsku, eksportuje 90\% swojej produkcji, z czego $80 \%$ na rynek niemiecki.

Przemysł drzewny Pomorza Środkowego stosunkowo dobrze przeszedł przez pierwsze lata przeobrażeń gospodarczych jakie zaszły w Polsce po 1989 r. Już w 1992 r. wysunął się na drugą pozycję (za przemysłem spożywczym) pod względem zatrudnienia pozarolniczego. W przeciwieństwie do przemysłu skórzano-obuwniczego w przemyśle drzewnym nie nastąpiły drastyczne redukcje zatrudnienia, nie doszło także do dewastacji lub masowej wyprzedaży, często za bezcen, środków trwałych. Stosunkowo szybko, zwłaszcza w meblarstwie, nastąpiły procesy restrukturyzacji i prywatyzacji, przez co utrzymano wysokie zatrudnienie, zmodernizowano większość linii produkcyjnych oraz wdrożono nowoczesne formy promocji i sprzedaży. Brak rodzimego kapitału inwestycyjnego zastapił kapitał obcy (szczególnie niemiecki), który zainwestował bardzo szeroko we wszystkie niemal branże. Wśród firm zagranicznych obok prawdziwych gigantów (np. Schieder Mobel Holding $\mathrm{GmbH}$ ) znalazły się także firmy niewielkie z Niemiec, Szwecji, Danii i in. Reasumując, przemysł drzewny jest jedną z nielicznych sfer produkcji pozarolniczej Pomorza Środkowego, która wydaje się być konkurencyjną na rynku krajowym.

\section{Literatura}

Gasztold T., Muszyński A., Rybicki H., 1974, Koszalin. Zarys dziejów. WP, Poznań. Gierszewski S. (red.), 1981, Historia Stupska, WP, Poznań.

Kortus B., 1986, Wstep do geografii przemystu, PWN, Warszawa.

Lindmajer J., Machura T., Spors B., Wachowiak B., 1986, Dzieje Stupska, PTN, Słupsk. Machura T. 1974, Przemyst na Pomorzu Zachodnim 1945-1949, WP, Poznań.

\footnotetext{
* Rentowność brutto 1995 r. Dane wg BUSINESS SERVICE Ltd. w Poznaniu.
} 
Małuszyńska E., 1996, Problemy lokalizacji zagranicznych inwestycji przemystowych w Polsce ze szczególnym uwzględnieniem zachodnich województw przygranicznych, [w:] Materiały konferencyjne 45 Zjazdu PTG Stupsk-Ustka, WSP Słupsk, s. 277-280.

Rydz E., Jażewicz I., 1994, Przemiany struktur przestrzenno-gatęziowych przemystu województwa stupskiego $w$ zmieniajacych się warunkach gospodarowania, [w:] Zachowania przestrzenne przemystu w zmieniajacych się warunkach gospodarowania, Kraków - Warszawa, s. 132-144. 